\title{
President's Message: Membership, Leadership, Emerging Leaders, and LITA Karen J. Starr
}

n 2006, ALA President Leslie Burger implemented six initiatives, including an Emerging Leaders program that is now in its fifth year. The initiative was designed to prepare librarians who are new to the profession in leadership skills that are applicable on the job and as active leaders within the association. LITA is sponsoring 2011 emerging leaders Bohyun Kim and Andreas Orphanides. Bohyun is currently digital access librarian at the Florida International University Medical Library. Andreas is currently librarian for digital technologies and learning at the North Carolina State University Libraries. As of the writing of this column, the projects for 2011 have not been assigned. Additional LITA members accepted into the 2011 ALA Emerging Leaders Program include Tabatha Farney, Deana Greenfield, Amanda Harlan, Colleen Harris, Megan Hodge, Matthew Jabaily, Catherine Kosturski, Nicole Pagowsky, Casey Schacher, Sibyl Schaefer, Jessica Sender, and Andromeda Yelton.

LITA provides an ideal environment for its members to enhance their skills. In 2009, Emerging Leaders Team T developed a project "Making it Personal: Leadership Development Programs for LITA," working in consultation with the LITA Membership Development Committee. Team members included Amanda Hornby (University of Washington), Angelica Guerrero Fortin (San Diego County Library), Dan Overfield (Cuyahoga Community College), and Lisa Carlucci Thomas (Yale University).

The Team $\mathrm{T}$ members recommended the creation of "an online continuing education program to develop the leadership and project management skills necessary to maintain and promote the value and ability of LITA's professional membership to the greater librarian population." Outcomes for the training would include project-management and team-building skills within a context that focuses on the development and application of technology in libraries. The team members also recommended the establishing of a LITA mentorship program that would provide for educating mentees about LITA, sharing of areas of expertise and awareness, and develop a network of professionals.

Dialogue on the LITA electronic discussion list and conversations with committee and interest group chairs suggests a desire and need for leadership training. The Membership Development Committee is addressing the need for mentors in LITA 101 and LITA 201 held at ALA Annual Conferences and Midwinter Meetings. LITA leadership, including the Membership Development Committee, Committee and Interest Group Chairs, the Education Committee, LITA Emerging Leaders, and others, will be included in an ongoing dialogue to see how and what can be implemented from the LITA Leadership Institute and the LITA Mentorship Program recommendations as submitted by the 2009 Emerging Leaders Team T.

Follow-up by LITA to implement the recommendations of emerging leader projects is important to the vitality and longevity of the association. Since 2007, a number of projects have been developed by Emerging Leaders. Information about the projects is available at the following locations online:

- The ALA website: http:/ / www.ala.org/ala/educationcareerleader ship/emergingleaders/index.cfm

- ALA Connect: http:/ / connect.ala.org/emergingleaders

- Facebook: http:/ / www.facebook.com/pages/ALA-Emerging -Leaders /156736295251?ref=ts /

- The Emerging Leaders blog: http: / / connect.ala.org/2011emergingleaders

- The Emerging Leaders Wiki: http:/ /emergingleaders.ala.org/wiki/index.php ?title =Main_Page
Karen J. Starr (kstarr@ nevadaculture.org) is LITA President 2010-11 and Assistant Administrator for Library and Development Services, Nevada State Library and Archives, Carson City. 